2016

\title{
Indigenous Law and Aboriginal Title
}

Kent McNeil

Osgoode Hall Law School of York University, kmcneil@osgoode.yorku.ca

Follow this and additional works at: http://digitalcommons.osgoode.yorku.ca/all_papers

Part of the Indian and Aboriginal Law Commons

\section{Repository Citation}

McNeil, Kent, "Indigenous Law and Aboriginal Title" (2016). All Papers. 267.

http://digitalcommons.osgoode.yorku.ca/all_papers/267 


\title{
Indigenous Law and Aboriginal Title
}

\author{
(C) Kent McNeil \\ Osgoode Hall Law School \\ August 12, 2016
}

This paper discusses the relevance of Indigenous law to Aboriginal title in Canada, as revealed in three leading Supreme Court decisions: Delgamuukw v. British Columbia, ${ }^{1}$ R. v. Marshall; R. v. Bernard, ${ }^{2}$ and Tsilhqot'in Nation v. British Columbia. ${ }^{3}$ It concludes that Indigenous law relates to Aboriginal title in two ways: it is part of the evidence that can be relied upon to establish the exclusive occupation necessary for title at the time of Crown assertion of sovereignty, and it continues thereafter to govern the communal land rights of the Aboriginal titleholders. Moreover, the content of Indigenous law is not frozen at the moment of Crown sovereignty - it is dynamic and alterable by the Indigenous people concerned in accordance with their own system of governance.

This paper is extracted from a longer paper on St. Catherine's Milling and Lumber Company v. The Queen, ${ }^{4}$ which is why the discussion of the three Supreme Court decisions relates them to the Privy Council's decision in that early case.

\section{Delgamuukw v. British Columbia}

As anyone reading this paper is probably familiar with the Delgamuukw case, I am going to confine my discussion of it to Chief Justice Lamer's treatment of the St. Catherine's decision and his elaboration of the sources and nature of Aboriginal

\footnotetext{
${ }^{1}$ Delgamuukw v. British Columbia, [1997] 3 S.C.R. 1010 [Delgamuukw, S.C.C.].

2 [2005] 2 S.C.R. 220 [Marshall/Bernard].

${ }^{3}$ Tsilhqot'in Nation v. British Columbia, [2014] 2 S.C.R. 257 [Tsilhqot'in Nation, S.C.C.]

${ }^{4}$ (1888) 14 App. Cas. 46 [St. Catherine’s, P.C.].
} 
title. Regarding St. Catherine's, he stated:

The starting point of the Canadian jurisprudence on aboriginal title is the Privy Council's decision in St. Catherine's Milling and Lumber Co. v. The Queen (1888), 14 App. Cas. 46, which described aboriginal title as a "personal and usufructuary right" (at p. 54). The subsequent jurisprudence has attempted to grapple with this definition, and has in the process demonstrated that the Privy Council's choice of terminology is not particularly helpful to explain the various dimensions of aboriginal title. What the Privy Council sought to capture is that aboriginal title is a sui generis interest in land. Aboriginal title has been described as sui generis in order to distinguish it from "normal" proprietary interests, such as fee simple. However, as I will now develop, it is also sui generis in the sense that its characteristics cannot be completely explained by reference either to the common law rules of real property or to the rules of property found in aboriginal legal systems. As with other aboriginal rights, it must be understood by reference to both common law and aboriginal perspectives. ${ }^{5}$

On the "personal" aspect of Aboriginal title, Lamer C.J. explained that this simply means it is inalienable other than by surrender to the Crown, not that it is "a nonproprietary interest which amounts to no more than a licence to use and occupy the land and cannot compete on an equal footing with other proprietary interests”. 6

Turning to the source of Aboriginal title, he said that

... it had originally been thought that the source of aboriginal title in Canada was the Royal Proclamation, 1763: see St. Catherine's Milling. However, it is now clear that although aboriginal title was recognized by the Proclamation, it arises from the prior occupation of Canada by aboriginal peoples. That prior occupation, however, is relevant in two different ways, both of which illustrate the sui generis nature of aboriginal title. The first is the physical fact of occupation, which derives from the common law principle that occupation is proof of possession in law.... Thus, in Guerin [Guerin v. The Queen, [1984] 2 S.C.R. 335] Dickson J. described aboriginal title, at p. 376, as a

\footnotetext{
${ }^{5}$ Delgamuukw, S.C.C., above note 1 at para. 112.

${ }^{6}$ Ibid. at para. 113, citing Canadian Pacific Ltd. v. Paul, [1988] 2 S.C.R. 654 at 677.
} 
"legal right derived from the Indians' historic occupation and possession of their tribal lands”.... [I]n Roberts v. Canada, [1989] 1 S.C.R. 322, ... this Court unanimously held at p. 340 that "aboriginal title pre-dated colonization by the British and survived British claims of sovereignty" (also see Guerin at p. 378). What this suggests is a second source for aboriginal title - the relationship between common law and pre-existing systems of aboriginal law. ${ }^{7}$

Chief Justice Lamer thus followed the Court's rejection in Calder v. AttorneyGeneral of British Columbia ${ }^{8}$ of the Privy Council's ruling in St. Catherine's that Aboriginal title comes from the Royal Proclamation of 1763; instead, it is rooted in pre-colonization occupation of land by the Indigenous peoples and in their preexisting systems of law.

At common law, Chief Justice Lamer explained, "the fact of physical occupation is proof of possession at law, which in turn will ground title to the land". ${ }^{9}$ So if Aboriginal claimants are able to prove that they are descended from or are the successors to Indigenous people who were in exclusive occupation of specific lands at the time the British Crown asserted sovereignty, they will have Aboriginal title in the absence of adequate proof by the Crown of subsequent extinguishment of their title. ${ }^{10}$ Indigenous law is relevant to proof of occupation because an Indigenous land tenure system, laws governing land use, and trespass laws, to give Lamer C.J.'s examples, could be relied upon to establish the

\footnotetext{
${ }^{7}$ Delgamuukw, S.C.C., above note 1 at para. 114. Compare the concurring judgment of La Forest J., especially at para. 190: "the aboriginal right of possession is derived from the historic occupation and use of ancestral lands by aboriginal peoples. Put another way, 'aboriginal title' is based on the continued occupation and use of the land as part of the aboriginal peoples' traditional way of life.”

${ }^{8}$ [1973] S.C.R. 313.

${ }^{9}$ Delgamuukw, S.C.C., above note 1 at para. 149. For detailed discussion, see McNeil, Common Law Aboriginal Title (Oxford: Clarendon Press, 1989).

${ }^{10}$ Delgamuukw, S.C.C., above note 1. On extinguishment, see Kent McNeil, "Extinguishment of Aboriginal Title in Canada: Treaties, Legislation, and Judicial Discretion” (2001-2002) 33 Ottawa L. Rev. 301 [McNeil, “Extinguishment of Aboriginal Title”].
} 
exclusive occupation required for title. ${ }^{11}$ But if the only use of Indigenous law is as evidence of the occupation that grounds title at common law, can Indigenous law really be a second source of Aboriginal title, as Lamer C.J. suggested? His references to passages from Roberts $v$. Canada and Guerin in the quotation in the preceding paragraph certainly imply that Indigenous systems of law that were in existence at the time of Crown assertion of sovereignty continued thereafter and are relevant, not just as evidence of occupation at that time, but as a source of Aboriginal title in their own right. ${ }^{12}$ However, his description of the content of Aboriginal title is not consistent with what is known as the doctrine of continuity, whereby Aboriginal title to land based on and defined by Indigenous laws and customs pre-dated and continued after British colonization. ${ }^{13}$ If that doctrine applied to Aboriginal title in Canada, one would expect the content of that title to vary greatly in different parts of the country in accordance with the vast diversity in Indigenous cultures and land use. Instead, the Chief Justice's elaboration on the content of Aboriginal title reveals that it is what Brian Slattery has described as a generic right that does not vary from one Indigenous people to another. ${ }^{14}$

On content as well as source, Chief Justice Lamer's judgment also rejects Lord Watson's description of Aboriginal title in the St. Catherine's case. In that case, his Lordship not only referred to Aboriginal title as "a personal and

${ }^{11}$ Delgamuukw, S.C.C., above note 1 at paras. 148, 157.

12 The Guerin citation references the page where Dickson J. cited Amodu Tijani v. Secretary, Southern Nigeria, [1921] 2 A.C. 399 (P.C.), as authority that "a change in sovereignty over a particular territory does not in general affect the presumptive title of the inhabitants."

${ }^{13}$ See Brian Slattery, The Land Rights of Indigenous Canadian Peoples (Saskatoon: University of Saskatchewan Native Law Centre, 1979), 50-59; Mark D. Walters, "The 'Golden Thread' of Continuity: Aboriginal Customs at Common Law and Under the Constitution Act, 1982” (1999) 44 McGill L.J. 711; Kent McNeil and David Yarrow, "Has Constitutional Recognition of Aboriginal Rights Adversely Affected Their Definition?” (2007) 37 Supreme Court L. Rev. $\left(2^{\text {nd }}\right.$ ) 177 at 203-11.

${ }^{14}$ Brian Slattery, “A Taxonomy of Aboriginal Rights”, in Hamar Foster, Heather Raven, and Jeremy Webber, eds., Let Right Be Done: Aboriginal Title, the Calder Case, and the Future of Indigenous Rights (Vancouver: UBC Press, 2007), 111 at 118. 
usufructuary right”, but also dismissed the federal government's argument that the Saulteaux had "the entire property of the land", deciding instead that the "Crown has all along had a present proprietary estate in the land, upon which the Indian title was a mere burden.” ${ }^{15}$ Lamer C.J. avoided disagreeing directly with Lord Watson by remarking that, although his Lordship "described the aboriginal title as a 'personal and usufructuary right', [he] declined to explain what that meant because it was not 'necessary to express any opinion upon the point "'. ${ }^{16}$ Admitting that "the courts have been less than forthcoming" in defining Aboriginal title, Lamer C.J. addressed the issue directly and concluded that

... the content of aboriginal title can be summarized by two propositions: first, that aboriginal title encompasses the right to exclusive use and occupation of the land held pursuant to that title for a variety of purposes, which need not be aspects of those aboriginal practices, customs and traditions which are integral to distinctive aboriginal cultures; and second, that those protected uses must not be irreconcilable with the nature of the group's attachment to that land. ${ }^{17}$

He expressly rejected the Crown's argument that Aboriginal title is limited to traditional uses of the land, deciding instead that it is an all-encompassing property right that includes natural resources on and under the ground, subject only to an inherent limit that prevents the land from being used in ways that are irreconcilable with the relationship with the land giving rise to the Aboriginal title. ${ }^{18}$ Consequently, the land cannot be put to uses that would destroy its unique value to the Indigenous people in question, such as strip-mining a hunting ground or turning land that has special ceremonial or cultural significance into a parking lot, but

${ }^{15}$ St. Catherine's, P.C., above note 4 at 54, 58.

${ }^{16}$ Delgamuukw, S.C.C., above note 1 at para. 116, quoting St. Catherine's, P.C., above note 4 at 54, 55.

${ }^{17}$ Delgamuukw, S.C.C., above note 1 at para. 117.

${ }^{18}$ For discussion, see “The Post-Delgamuukw Nature and Content of Aboriginal Title”, in Kent McNeil, Emerging Justice? Essays on Indigenous Rights in Canada and Australia (Saskatoon: University of Saskatchewan Native Law Centre, 2001), 136 [McNeil, Emerging Justice?], 102. 
otherwise Aboriginal title "allows for a full range of uses of the land". ${ }^{19}$

So what role does Indigenous law play in relation to Aboriginal title, other than as part of the evidence that can be relied upon to prove exclusive occupation at the time of Crown assertion of sovereignty? While Chief Justice Lamer did not answer this question, surely Indigenous law did not cease to exist at that moment, to be instantaneously replaced by the common law and applicable statute law of England. $^{20}$ Such a result would have created legal chaos in Indigenous communities, as the law of England would have been unknown and unenforceable there at the time. In Delgamuukw, the Supreme Court accepted that Crown assertion of sovereignty in British Columbia took place in 1846, the year of the Oregon Boundary Treaty that established the boundary between British and American territory in the Pacific Northwest along the $49^{\text {th }}$ parallel. ${ }^{21}$ At the time, there was very little British presence in the territories of the Gitksan and Wet'suwet'en Nations whose rights were in question in Delgamuukw, and certainly

${ }^{19}$ Delgamuukw, S.C.C., above note 1 at paras. 128, 132. Note that the inherent limit has been modified somewhat in the Court's more recent decision in Tsilhqot'in Nation, S.C.C., above note 3 at para. 74, where McLachlin C.J. placed emphasis on forward-looking sustainability rather than on backward-looking protection of the land for traditional uses: see Brian Slattery, "The Constitutional Dimensions of Aboriginal Title” (2015) 71 Supreme Court L. Rev. (2d) 45 at 5863 [Slattery, “Constitutional Dimensions”].

${ }^{20}$ For legal opinions that this did not happen to French law when English law was introduced in Quebec by the Royal Proclamation of 1763, see C. Yorke and Wm de Grey, Report of Attorney and Solicitor General Regarding the Civil Government of Quebec, to the Lords of the Committee of Council for Plantation Affairs in London, 14 April 1766, in Adam Shortt and Arthur G.

Doughty, Documents Relating to the Constitutional History of Canada, 1759-1791 (Ottawa: J. de L. Taché, Printer to the King’s Most Excellent Majesty, 1918), 251-57, especially 254-55; Report of Solicitor General Alex. Wedderburn, 6 December 1772, ibid. at 424-37, especially 425; Report of Attorney General, Edwd. Thurlow, 22 January 1773, ibid. at 437-45, especially 440-44; Drulard v. Welsh (1906) 11 O.L.R. 647 (Ont. Div. Ct.), reversed on other grounds, (1907) 14 O.L.R. 54 (Ont. C.A.).

${ }^{21}$ Delgamuukw, S.C.C., above note 1 at para. 145. For critical assessment, see Kent McNeil, "Negotiated Sovereignty: Indian Treaties and the Acquisition of American and Canadian Territorial Rights in the Pacific Northwest”, in Alexandra Harmon, ed., The Power of Promises: Rethinking Indian Treaties in the Pacific Northwest (Seattle: University of Washington Press, 2008), 35. 
no British police officers, judges, or other government officials. Gitksan and Wet'suwet'en life carried on as before, necessarily governed by their own laws and their own systems of governance. ${ }^{22}$

Yet Aboriginal title to the lands exclusively occupied by the Gitksan and Wet'suwet'en Nations vested in them the moment the Crown asserted sovereignty in $1846 .{ }^{23}$ This title, as described by Chief Justice Lamer, gave them a right to exclusive possession and use of the land that would, in principle, have been legally enforceable from that time forward, disregarding the practical aspects involved in enforcement against the Crown and third parties. Exclusivity as against the outside world is the external dimension of Aboriginal title that allows it to "compete on an equal footing with other proprietary interests”. ${ }^{24}$ But in his judgment Lamer C.J. did not explain how the right of possession and use that Aboriginal title confers operates internally, other than to say that aboriginal title "is a collective right to land held by all members of an aboriginal nation” and that “[d]ecisions with respect to that land are also made by that community." 25 The evidence presented at trial revealed that, from time immemorial, the Gitksan and Wet'suwet'en have had complex systems of law that govern land holding and use within their communities. ${ }^{26}$ As both a practical and legal matter, those laws would have

\footnotetext{
${ }^{22}$ See Delgamuukw v. British Columbia, (1991) 79 D.L.R. (4th) 185 (B.C.S.C.) [Delgamuukw, B.C.S.C.], headings “5. The Historical Period” and "6. The Colony of British Columbia”.

${ }^{23}$ Delgamuukw, S.C.C., above note 1, Lamer C.J. at para. 145: “aboriginal title crystallized at the time sovereignty was asserted.” For reasons relating to the way the case was pleaded and the way the trial judge dealt with the oral histories, the Supreme Court did not issue a declaration of title, deciding instead to send the matter back to trial to determine what lands had been exclusively occupied by the Gitksan and Wet'suwet'en in 1846. The case has not been retried.

${ }^{24}$ Ibid. at para. 113.

${ }^{25}$ Ibid. at para. 115.

${ }^{26}$ See Delgamuukw, B.C.S.C., above note 22. See also Richard Overstall, "Encountering the Spirit in the Land: 'Property' in a Kinship-Based Legal Order”, in John McLaren, A.R. Buck, and Nancy E. Wright, eds., Despotic Dominion: Property Rights in British Settler Societies (Vancouver: UBC Press, 2005), 22; Valerie Ruth Napoleon, “Ayook: Gitksan Legal Order, Law, and Legal Theory”, unpublished Ph.D. dissertation, University of Victoria Faculty of Law, 2009.
} 
continued in force after Crown assertion of sovereignty in 1846, and would necessarily have been alterable by those nations through the exercise of their decision-making authority, which given the communal nature of their rights would have to be governmental in nature. ${ }^{27}$

So "the relationship between common law and pre-existing systems of aboriginal law" that Chief Justice Lamer suggested "is a second source for aboriginal title" 28 can be understood by taking into account the fact that Aboriginal title has two dimensions, one external and the other internal. The external dimension arises from exclusive occupation of land and the exclusive rights of possession and use that the common law confers against the outside world. Indigenous law can be used to help prove the exclusive occupation giving rise to this external dimension, but it does not apply to define the rights externally. Nor does it define the content of those rights, as the content does not vary from one group of Indigenous people to another, regardless of variation in their legal orders. It does, however, apply internally to govern the rights and authority of the Aboriginal titleholders among themselves and in relation to others who seek to use

\footnotetext{
${ }^{27}$ See Brian Slattery, “The Metamorphosis of Aboriginal Title” (2006) 85 Can. Bar Rev. 255 at 270 [Slattery, "Metamorphosis”]; Slattery, “Constitutional Dimensions”, above note 19 at 52-54; Jeremy Webber, “The Public Law Dimension of Indigenous Property Rights”, in Nigel Bankes and Timo Koivurova, eds., The Proposed Nordic Saami Convention: National and International Dimensions of Indigenous Property Rights (Oxford: Hart Publishing, 2013), 79. Aboriginal nations' inherent right of self-government over their Aboriginal title lands was acknowledged by Williamson J. in Campbell v. British Columbia, [2000] 4 C.N.L.R. 1 (B.C.S.C.): see discussion in Kent McNeil, “Judicial Approaches to Self-Government since Calder: Searching for Doctrinal Coherence”, in Foster, Raven, and Webber, above note 14, 129 at 139-43. In House of Sga'nisim v. Canada (Attorney General), [2012] 2 C.N.L.R. 82 (B.C.S.C.), Smith J. followed Campbell out of comity, but also held that the governance provisions of the Nisga'a Final Agreement, 1998, the validity of which was challenged in these cases, could be upheld as delegated governmental authority. Smith J.'s decision was affirmed on appeal on the latter basis, without deciding the inherent right issue: 2013 BCCA 49, [2013] 2 C.N.L.R. 226, leave to appeal refused, [2013] S.C.C.A. No. 44. For commentary, see Joshua Nichols, "A Reconciliation without Recollection? Chief Mountain and the Sources of Sovereignty” (2015) 48 U.B.C. L. Rev. 515.

${ }^{28}$ Delgamuukw, S.C.C., above note 1 at para. 114.
} 
their lands. Indigenous law is therefore a source of their internal communal rights, whereas the common law is a source of their external rights. Aboriginal title can therefore only be understood by reference to both systems of law and by taking into account the relationship between them. To repeat Chief Justice Lamer's words, "its characteristics cannot be completely explained by reference either to the common law rules of real property or to the rules of property found in aboriginal legal systems. As with other aboriginal rights, it must be understood by reference to both common law and aboriginal perspectives." ${ }^{29}$ And given that it would be impractical and even absurd for the Indigenous law governing internal rights to be arbitrarily frozen at the moment of Crown assertion of sovereignty, Aboriginal titleholders must have the authority to alter their laws in relation to land as their societies and the environments in which they live change. This authority to make and revise law is necessarily governmental.

\section{R. v. Marshall; R. v. Bernard}

$R$. $v$. Marshall and $R$. $v$. Bernard are companion cases arising out of prosecutions under provincial legislation in Nova Scotia and New Brunswick for illegal harvesting and possession of timber from Crown land. The accused Mi’kmaqs raised treaty rights and Aboriginal title as defences. The Supreme Court issued a single judgment, rejecting these defences and upholding the convictions imposed at trial. Chief Justice McLachlin delivered the main judgment, with Justice LeBel delivering a judgment for himself and Justice Fish that concurred in result but differed substantially in reasons. The focus of the judgments was on proof of Aboriginal title, with all the judges agreeing that the evidence did not establish the exclusive occupation of the cutting sites needed to prove Aboriginal title. ${ }^{30}$

\footnotetext{
${ }^{29}$ Ibid. at para. 112.

${ }^{30}$ On whether the occupation needs to be site-specific, see Kent McNeil, “Aboriginal Title in
} 
Given the focus on proof, McLachlin C.J. did not have a lot to say about the sources and content of Aboriginal title. Nor did she mention the St. Catherine's case, even in the context of the Royal Proclamation of 1763, which the accused argued had "reserved to the Mi'kmaq title in all unceded, unpurchased land in the former Nova Scotia, which later was divided into Nova Scotia and New Brunswick." ${ }^{31}$ Without referring to either Calder or Delgamuukw in this context, she affirmed the rulings in those decisions that the Proclamation is not an independent source of Aboriginal title, implicitly deciding that it affirms preexisting rights rather than creating new ones. ${ }^{32}$

Chief Justice McLachlin’s discussion of Aboriginal title emphasized the role of the common law, starting with this statement: "Where title to lands formerly occupied by an aboriginal people has not been surrendered, a claim for aboriginal title to the land may be made under the common law." ${ }^{33}$ Relying on Delgamuukw, she nonetheless acknowledged that, in assessing claims to Aboriginal title, "the Court must consider both the aboriginal perspective and the common law perspective." ${ }^{34}$ She then elaborated on what this means:

The Court's task in evaluating a claim for an aboriginal right is to examine the pre-sovereignty aboriginal practice and translate that practice, as faithfully and objectively as it can, into a modern legal right.... This exercise involves both aboriginal and European perspectives. The Court must consider the pre-sovereignty practice from the perspective of the aboriginal people. But in translating it to a common law right, the Court must also consider the European perspective; the nature of the right at common law must be examined to determine whether a particular aboriginal practice fits it. ${ }^{35}$

Canada: Site-Specific or Territorial?” (2012) 91 Can. Bar Rev. 745 [McNeil, “Aboriginal Title in Canada"], and Tsilhqot'in Nation, S.C.C., above note 3.

${ }^{31}$ Marshall/Bernard, above note 2 at para. 85.

${ }^{32}$ LeBel and Fish JJ. concurred on this issue: ibid. at para. 111.

33 Ibid. at para. 38.

${ }^{34}$ Ibid. at para. 46.

${ }^{35}$ Ibid. at para. 48. 
She emphasized that "to insist that the pre-sovereignty practices correspond in some broad sense to the modern right claimed, is not to ignore the aboriginal perspective. The aboriginal perspective grounds the analysis and imbues its every step. It must be considered in evaluating the practice at issue, and a generous approach must be taken in matching it to the appropriate modern right.”36

In the passages just quoted, Chief Justice McLachlin was referring to Aboriginal rights generally, but she then applied the same methodology of translating practices into rights to Aboriginal title. "One of these rights”, she said, "is aboriginal title to land. It is established by aboriginal practices that indicate possession similar to that associated with title at common law. In matching common law property rules to aboriginal practice we must be sensitive to the context-specific nature of common law title, as well as the aboriginal perspective.” ${ }^{37}$ Sensitivity to the Aboriginal perspective involves evaluating the practices from the point of view of the Aboriginal society and taking their manner of life into account. McLachlin C.J. elaborated by quoting with approval the following passage from La Forest J.’s concurring judgment in Delgamuukw:

... when dealing with a claim of "aboriginal title", the court will focus on the occupation and use of the land as part of the aboriginal society's traditional way of life. In pragmatic terms, this means looking at the manner in which the society used the land to live, namely to establish villages, to work, to get to work, to hunt, to travel to hunting grounds, to fish, to get to fishing pools, to conduct religious rites, etc. [Emphasis in original]. ${ }^{38}$

But the practices must be sufficient to prove occupation as a matter of fact in order

\footnotetext{
${ }^{36}$ Ibid. at para. 50.

${ }^{37}$ Ibid. at para. 54.

${ }^{38} \mathrm{Ibid}$. at para. 49, quoting from Delgamuukw, S.C.C., above note 1 at para. 194.
} 
to be translated into title at common law, ${ }^{39}$ and ““[o]ccupation' means 'physical occupation'. This 'may be established in a variety of ways, ranging from the construction of dwellings through cultivation and enclosure of fields to regular use of definite tracts of land for hunting, fishing or otherwise exploiting its resources'.,40

For the purposes of this paper, Chief Justice McLachlin's judgment in Marshall/Bernard is remarkable for a couple of reasons. First, it conflates proof of Aboriginal title and other Aboriginal rights, so that both depend on historical practices that are then translated into modern-day rights. While this methodology may work for hunting, fishing, and wood harvesting rights that are usually based on practices that give rise to these specific rights, ${ }^{41}$ with all due respect I question its application to Aboriginal title. ${ }^{42}$ As we have seen, the common law source of Aboriginal title is occupation of land, which is based in part on practices, but as Chief Justice Lamer stated in Delgamuukw, it can also be established through proof of Indigenous law, such trespass laws and laws governing land tenure and use. ${ }^{43}$ When she said that ““[o]ccupation' means 'physical occupation””, McLachlin C.J. disregarded the relevance of Indigenous law to proof of occupation. Moreover, where Aboriginal title rather than other Aboriginal rights is concerned, it is not the practices that get translated into rights; instead, the practices are evidence of

\footnotetext{
${ }^{39}$ Marshall/Bernard, above note 2 at para. 54.

${ }^{40}$ Ibid. at para. 56, McLachlin C.J. quoting in the last sentence from Lamer C.J. in Delgamuukw, S.C.C., above note 1 at para. 149.

${ }^{41}$ Though Aboriginal rights are based on "practices, customs and traditions”, which can include Indigenous laws (see R. v. Van der Peet, [1996] 2 S.C.R. 507, Lamer C.J. at paras. 44-48, McLachlin J., dissenting on other grounds, at paras. 263-69), in the numerous cases since Van der Peet the focus of the evidence has usually been on practices: e.g. see $R$. v. Adams, [1996] 3 S.C.R. 101; R. v. Côté, [1996] 3 S.C.R. 139; R. v. Sappier; R. v. Gray, [2006] 2 S.C.R. 686; Lax Kw’alaams Indian Band v. Canada (Attorney General), [2011] 3 S.C.R. 535.

${ }^{42}$ For more detailed critical discussion, see Kent McNeil, "Aboriginal Title and the Supreme Court: What’s Happening?” (1996) 69 Sask. L. Rev. 281, especially at 297-300.

${ }^{43}$ Delgamuukw, S.C.C., above note 1 at paras. 148, 157.
} 
occupation, which then gives rise to title. As we have seen, the title is uniform visà-vis the outside world - unlike other Aboriginal rights, its content does not depend on the nature of the practices relied upon as evidence of the requisite occupation. ${ }^{44}$

Secondly, McLachlin C.J. did not refer at all to the parts of Lamer C.J.'s decision in Delgamuukw suggesting that Indigenous law and the relationship between it and the common law are a second source of Aboriginal title. ${ }^{45}$ From her judgment in Marshall/Bernard, it appears that she thought there is only one source of Aboriginal title - physical occupation of land. ${ }^{46}$

While agreeing that there was not sufficient evidence to support findings of Aboriginal title in Marshall/Bernard, Justice LeBel took a very different approach to title that sheds light on its source. Like McLachlin C.J., he did not mention the Privy Council decision in the St. Catherine's case, but interestingly he did refer to Ritchie C.J.'s judgment in the Supreme Court of Canada in the case, noting that the Chief Justice had first used the concept of a usufruct "as an analogy to explain the relationship between Crown and aboriginal interests in the land.... A usufructuary title to all unsurrendered lands is understood to protect aboriginal peoples in the absolute use and enjoyment of their lands." ${ }^{47}$ So although Indigenous land use varied greatly in different parts of Canada, the "fact that a tract of land was used for hunting instead of agriculture does not mean that the group did not possess the land in such a way as to acquire aboriginal title." 48 For LeBel J., the concept of a usufruct therefore conferred the entire dominium utile on the Aboriginal titleholders, regardless of the uses they made of the land prior to Crown assertion of

\footnotetext{
${ }^{44}$ See text accompanying notes 14 and 17 above.

${ }^{45}$ See the quotations from Delgamuukw, S.C.C., above note 1, accompanying notes 5 and 7 above.

${ }^{46}$ For further discussion, see McNeil, “Aboriginal Title in Canada”, above note 30.

${ }^{47}$ Marshall/Bernard, above note 2 at para. 135 [emphasis added], referring to St. Catharines Milling and Lumber Company v. The Queen (1887) 13 S.C.R. 577.

${ }^{48}$ Marshall/Bernard, above note 2 at para. 136.
} 
sovereignty.

On the Aboriginal perspective, Justice LeBel observed that "aboriginal conceptions of territoriality, land-use and property should be used to modify and adapt the traditional common law concepts of property in order to develop an occupancy standard that incorporates both the aboriginal and common law approaches." 49 He acknowledged that "Aboriginal title has been recognized by the common law and is in part defined by the common law, but it is grounded in aboriginal customary laws relating to land. The interest is proprietary in nature and is derived from inter-traditional notions of ownership." 50 Addressing the matter of source directly, he said that "aboriginal title arises from the prior possession of land and the prior social organization and distinctive cultures of aboriginal peoples on that land.... It originates from 'the prior occupation of Canada by aboriginal peoples' and from 'the relationship between common law and pre-existing systems of aboriginal law' (Delgamuukw, at para. 114).”51 So unlike McLachlin C.J., Justice LeBel relied expressly on Lamer C.J.'s articulation of the dual sources of Aboriginal title in the common law and Indigenous law, and the relationship between them. He also disagreed with her view that the role of the Aboriginal perspective is "simply to help in the interpretation of aboriginal practices in order to assess whether they conform to common law concepts of title.”52 On the contrary, he said, "[t]he aboriginal perspective shapes the very concept of aboriginal title”, relying on John Borrows’ assertion that “Aboriginal law should not just be received as evidence that Aboriginal peoples did something in the past on a piece of land. It

\footnotetext{
${ }^{49}$ Ibid. at para. 127.

${ }^{50}$ Ibid. at para. 128.

${ }^{51}$ Ibid. at para. 129. LeBel J. also quoted Lamer C.J.'s statement that Aboriginal title “cannot be completely explained by reference either to the common law rules of real property or to the rules of property found in aboriginal legal systems. As with other aboriginal rights, it must be understood by reference to both common law and aboriginal perspectives": ibid., quoting from Delgamuukw, S.C.C., above note 1 at para. 112.

${ }^{52}$ Marshall/Bernard, above note 2 at para. 130.
} 
is more than evidence: it is actually law."53

Justice LeBel therefore seems to have regarded the role of Indigenous law as two-fold: it has to be taken into account in shaping the concept of Aboriginal title, but it is also part of the Aboriginal perspective on the occupation necessary to establish Aboriginal title. On the latter function, he stated in evident reference to Lamer C.J.'s decision in Delgamuukw that the "aboriginal perspective on the occupation of their land can also be gleaned in part, but not exclusively, from presovereignty systems of aboriginal law. The relevant laws consisted of elements of the practices, customs and traditions of aboriginal peoples and might include a land tenure system or laws governing land use." ${ }^{54}$ As we have seen, this function of Indigenous law as evidence of occupation is an important aspect of Lamer C.J.'s judgment that was ignored by Chief Justice McLachlin in her majority decision in Marshall/Bernard. However, I am less sure of what Justice LeBel had in mind when he said that the Aboriginal perspective, which includes Indigenous law, "shapes the very concept of aboriginal title." ${ }^{55}$ As discussed above, the Aboriginal title that Lamer C.J. described in Delgamuukw is generic in nature, and so does not vary from one instance to another. Yet Indigenous law does vary greatly across Canada, ${ }^{56}$ so if that law shapes the concept of title one would expect the title to vary as well. This cannot be what LeBel J. meant, as he relied heavily on Lamer C.J.'s judgment and appears to have been critical of McLachlin C.J. for not following it more closely. His remarks on the usufructuary nature of Aboriginal title cited earlier also reveal that he regarded Aboriginal title as entailing the entire beneficial interest

\footnotetext{
53 Ibid., quoting John Borrows, “Creating an Indigenous Legal Community” (2005) 50 McGill L.J. 153, at 173.

${ }^{54}$ Marshall/Bernard, above note 2 at para. 139, paraphrasing Delgamuukw, S.C.C., above note 1 at para. 148.

${ }^{55}$ Marshall/Bernard, above note 2 at para. 130.

${ }^{56}$ See John Borrows, Canada's Indigenous Constitution (Toronto: University of Toronto Press, 2010).
} 
in the land, regardless of the Indigenous uses in the past. ${ }^{57}$ Perhaps this apparent tension in his judgment can be resolved by adopting the external/internal dichotomy of Aboriginal title outlined above: vis-à-vis the outside world, Aboriginal title entails generic rights that arise at common law from exclusive occupation, whereas internally, Aboriginal title is governed by pre-existing Indigenous law that continued after Crown assertion of sovereignty and is alterable through the exercise of Indigenous peoples' governance authority. ${ }^{58}$

This brings us to the most recent Supreme Court decision on Aboriginal title, Tsilhqot'in Nation, that resolved some but not all of the uncertainties in the earlier jurisprudence.

\section{Tsilhqot'in Nation v. British Columbia ${ }^{59}$}

As is well known, in Tsilhqot'in Nation the Supreme Court issued a declaration of Aboriginal title for the first time in Canadian judicial history. This happened because the factual record, based on extensive evidence presented at trial, led the Supreme Court to accept the conclusion of Justice Vickers that the Tsilhqot'in had proven their title over a large portion of the claim area in accordance with the test laid down by the Court in Delgamuukw. ${ }^{60}$

In her unanimous judgment, Chief Justice McLachlin settled a number of

\footnotetext{
${ }^{57}$ See Marshall/Bernard, above note 2 at para. 136, where LeBel J. also stated (somewhat enigmatically in my view) in reference to the concept of a usufruct that, "[i]f this form of dominium utile is recognized as belonging to aboriginal peoples and the dominium directum is considered to be in the Crown, then it seems to follow that the test for proof of aboriginal title cannot simply reflect common law concepts of property and ownership.”

${ }^{58}$ See Brian Slattery, "The Generative Structure of Aboriginal Rights", in Patrick Macklem and Douglas Sanderson, eds., From Recognition to Reconciliation: Essays on the Constitutional Entrenchment of Aboriginal and Treaty Rights (Toronto: University of Toronto Press, 2016), 100, especially at 104, 106; Slattery, "Metamorphosis”, above note 27 at 270; Slattery, "Constitutional Dimensions", above note 19 at 52-54.

${ }^{59}$ Tsilhqot'in Nation, S.C.C., above note 3.

${ }^{60} \mathrm{Ibid}$. at paras. 51-66.
} 
issues, such as making clear that Aboriginal title is territorial rather than sitespecific, and deciding that the doctrine of interjurisdictional immunity no longer operates to prevent provincial laws from applying to Aboriginal title lands. ${ }^{61}$ She did not refer to the St. Catherine's case once in her judgment, instead starting her historical review of the jurisprudence on Aboriginal title and other Aboriginal rights with Calder. After summarizing the main principles from the case law governing Aboriginal title and rights, and deciding that lack of precise delineation of the territorial boundaries of Aboriginal title in the pleadings is not a reason for dismissing title claims, ${ }^{62}$ she moved on to the test for proving Aboriginal title. Relying on Delgamuukw, she affirmed that Aboriginal title depends on proof of exclusive occupation of land at the time of Crown assertion of sovereignty, which in British Columbia occurred in 1846. In so doing, she accepted that exclusive occupation is the source of Aboriginal title.

In assessing whether the evidence has met the requirements for proof of Aboriginal title - namely, sufficiency of occupation, continuity (where present occupation is relied upon to show occupation at the time of Crown sovereignty), and exclusivity - McLachlin C.J. cautioned that

... the court must be careful not to lose or distort the Aboriginal perspective by forcing ancestral practices into the square boxes of common law concepts, thus frustrating the goal of faithfully translating pre-sovereignty Aboriginal interests into equivalent modern legal rights. Sufficiency, continuity and exclusivity are not ends in themselves, but inquiries that shed light on whether Aboriginal title is established. ${ }^{63}$

\footnotetext{
${ }^{61}$ For further discussion, see Kent McNeil, "Exclusive Occupation and Joint Aboriginal Title” (2015) 48 U.B.C. L. Rev. 82 [McNeil, “Exclusive Occupation”], and "Aboriginal Title and the Provinces after Tsilhqot’in Nation” (2015) 71 Supreme Court L. Rev. (2d) 67 [McNeil, "Aboriginal Title and the Provinces"].

${ }^{62}$ At trial, Vickers J. declined to issue a declaration of title because, even though he found that title had been proven over a large area of land, the claim area described in the pleadings included lands where title had not been proven: Tsilhqot'in Nation v. British Columbia, [2008] 1 C.N.L.R. 112 (B.C.S.C.) [Tsilhqot'in Nation, B.C.S.C.], at paras. 102-30.

63 Tsilhqot'in Nation, S.C.C., above note 3 at para. 32.
} 
Turning to the sufficiency requirement, which she said "lies at the heart of this appeal", she said it "must be approached from both the common law perspective and the Aboriginal perspective", and that the "Aboriginal perspective focuses on laws, practices, customs and traditions of the group (Delgamuukw, at para. 148)." ${ }^{64}$ Inclusion of "laws" here is significant because, as we have seen, that aspect of the Aboriginal perspective was not mentioned in her judgment in Marshall/Bernard. The question, then, is what role do Indigenous laws play.

Chief Justice McLachlin's discussion of the sufficiency requirement focuses on actual presence on, control, and use of land:

To sufficiently occupy the land for purposes of title, the Aboriginal group in question must show that it has historically acted in a way that would communicate to third parties that it held the land for its own purposes. This standard does not demand notorious or visible use akin to proving a claim for adverse possession, but neither can the occupation be purely subjective or internal. There must be evidence of a strong presence on or over the land claimed, manifesting itself in acts of occupation that could reasonably be interpreted as demonstrating that the land in question belonged to, was controlled by, or was under the exclusive stewardship of the claimant group. As just discussed, the kinds of acts necessary to indicate a permanent presence and intention to hold and use the land for the group's purposes are dependent on the manner of life of the people and the nature of the land. Cultivated fields, constructed dwelling houses, invested labour, and a consistent presence on parts of the land may be sufficient, but are not essential to establish occupation. The notion of occupation must also reflect the way of life of the Aboriginal people, including those who were nomadic or seminomadic. ${ }^{65}$

Summing up, she said that

... what is required is a culturally sensitive approach to sufficiency of occupation based on the dual perspectives of the Aboriginal group in

\footnotetext{
${ }^{64}$ Ibid. at paras. 33-35.

${ }^{65}$ Ibid. at para. 38.
} 
question - its laws, practices, size, technological ability and the character of the land claimed - and the common law notion of possession as a basis for title.... The common law test for possession which requires an intention to occupy or hold land for the purposes of the occupant - must be considered alongside the perspective of the Aboriginal group which, depending on its size and manner of living, might conceive of possession of land in a somewhat different manner than did the common law. ${ }^{66}$

At no point in her discussion did Chief Justice McLachlin explain how Indigenous laws operate to establish sufficiency of occupation. They are part of the Aboriginal perspective, presumably shedding light on the nature of the Indigenous people's relationship with the land. But the only concrete example of how Indigenous law relates to the occupancy required for title was provided in her discussion of exclusivity, where she quoted with approval the following passage from Lamer C.J.'s judgment in Delgamuukw:

A consideration of the aboriginal perspective may also lead to the conclusion that trespass by other aboriginal groups does not undermine, and that presence of those groups by permission may reinforce, the exclusive occupation of the aboriginal group asserting title. For example, the aboriginal group asserting the claim to aboriginal title may have trespass laws which are proof of exclusive occupation, such that the presence of trespassers does not count as evidence against exclusivity. As well, aboriginal laws under which permission may be granted to other aboriginal groups to use or reside even temporarily on land would reinforce the finding of exclusive occupation. Indeed, if that permission were the subject of treaties between the aboriginal nations in question, those treaties would also form part of the aboriginal perspective. ${ }^{67}$

It therefore appears that the role of Indigenous law is as evidence of the exclusive occupation required for title. Nowhere in her judgment does McLachlin C.J. adopt

\footnotetext{
${ }^{66}$ Ibid. at para. 41.

${ }^{67}$ Delgamuukw, S.C.C., above note 1 at para. 157, quoted in Tsilhqot'in Nation, S.C.C., above note 3 at para. 49 .
} 
Lamer C.J.’s suggestion in Delgamuukw that Indigenous law and the relationship between it and the common law can be a second source of Aboriginal title.

So what happened to Tsilhqot'in law at the moment of Crown assertion of sovereignty in 1846? Chief Justice McLachlin clearly envisaged its existence up to then, but did not explain whether or how it operates from that time forward. However, as demonstrated by the factual findings of Justice Vickers in Tsilhqot'in Nation, the British presence in the Tsilhqot'in territory in 1846 was no greater than in the territories of the Gitksan and Wet'suwet'en further north. ${ }^{68}$ The Oregon Boundary Treaty of that year was really a non-event for the Tsilhqot'in, as they continued to live by their laws and govern themselves thereafter. ${ }^{69}$ So as discussed above in relation to the Gitksan and Wet'suwet'en, internally the Tsilhqot'in's Aboriginal title must be sourced in and continue to be regulated by their own laws and governance authority. And yet, in her discussion of the application of provincial laws to their Aboriginal title lands, McLachlin C.J. suggested that there could be a legal vacuum if provincial legislation was excluded by the doctrine of interjurisdictional immunity. ${ }^{70}$ What about Tsilhqot'in law? If it survived Crown assertion of sovereignty and continued after 1846, as it must have, how and when did it cease to be in effect? With respect, I think the Supreme Court has overlooked these questions and failed to take the continuing application of Tsilhqot'in law and governance authority into account. ${ }^{71}$

Externally, Chief Justice McLachlin affirmed the description of the nature and content of Aboriginal title presented by Lamer C.J. in Delgamuukw. Relying on Dickson J.’s judgment in Guerin, she stated:

\footnotetext{
${ }^{68}$ See Tsilhqot'in Nation, B.C.S.C., above note 62 paras. 232-58.

${ }^{69}$ On Tsilhqot'in governance and laws, see ibid. at paras. 356-63, 426-32.

${ }^{70}$ Tsilhqot'in Nation, S.C.C., above note 3 at para. 147.

${ }^{71}$ For further discussion, see McNeil, “Aboriginal Title and the Provinces”, above note 61 at 85 88; Andrée Boisselle, “To Dignity Through the Back Door: Tsilhqot'in and the Aboriginal Title Test” (2015) 71 Supreme Court L. Rev. $\left(2^{\text {nd }}\right) 27$.
} 
At the time of assertion of European sovereignty, the Crown acquired radical or underlying title to all the land in the province. This Crown title, however, was burdened by the pre-existing legal rights of Aboriginal people who occupied and used the land prior to European arrival. The doctrine of terra nullius (that no one owned the land prior to European assertion of sovereignty) never applied in Canada, as confirmed by the Royal Proclamation of 1763. The Aboriginal interest in land that burdens the Crown's underlying title is an independent legal interest, which gives rise to a fiduciary duty on the part of the Crown. ${ }^{72}$

From this passage, it appears that the Crown could acquire the radical or underlying title to Tsilhqot'in lands by mere assertion, despite the fact that there was no British governmental presence in the Tsilhqot'in territory and no way of enforcing English law there. ${ }^{73}$ But as discussed above, in principle this must mean that the Tsilhqot'in's Aboriginal title, which at common law also vested at same time in $1846,{ }^{74}$ was protected by that law against the outside world, including the Crown, from then on. ${ }^{75}$ This is the external aspect of Aboriginal title. At the time, the Crown's underlying title would have been purely notional, whereas the internal Aboriginal title of the Tsilhqot'in under their own laws and governance authority would have been very real. But even after the Crown did establish its own

\footnotetext{
${ }^{72}$ Tsilhqot'in Nation, S.C.C., above note 3 at para. 69.

${ }^{73}$ For critical commentary, see John Borrows, “The Durability of Terra Nullius: Tsilhqot'in Nation v British Columbia” (2015) 48 U.B.C. L. Rev. 701; Felix Hoehn, "Back to the Future Reconciliation and Indigenous Sovereignty after Tsilhqot'in” (2016) 67 U.N.B. L. Rev. 109; Kent McNeil, “The Doctrine of Discovery Reconsidered: Reflecting on Robert J Miller, Jacinta Ruru, Larissa Behrendt, and Tracey Lindberg, Discovering Indigenous Lands: The Doctrine of Discovery in the English Colonies and Felix Hoehn, Reconciling Sovereignties: Aboriginal Nations and Canada”, forthcoming 53:2 Osgoode Hall L.J.

${ }^{74}$ Delgamuukw, S.C.C., above note 1 at para. 145.

${ }^{75}$ As a property right that could "compete on an equal footing with other proprietary interests" (Delgamuukw, S.C.C., above note 1 at para. 113), Aboriginal title would be entitled to the same common law protection as other property rights: see Kent McNeil, “Aboriginal Title as a Constitutionally Protected Property Right”, in Owen Lippert, ed., Beyond the Nass Valley: National Implications of the Supreme Court's Delgamuukw Decision (Vancouver: The Fraser Institute, 2000), 55, republished in McNeil, Emerging Justice?, above note 18 at 292; McNeil, "Extinguishment of Aboriginal Title”, above note 10.
} 
governmental authority over the Tsilhqot'in territory, which may have occurred as a result of the Chilcotin War in the $1860 \mathrm{~s},{ }^{76}$ Tsilhqot'in law and governance in relation to land must have continued, both as a practical matter and as a matter of law. There is no other way their Aboriginal title could have been operational on the ground, as there would have been no applicable statute or common law to govern their communal enjoyment and use of the land internally. ${ }^{77}$

Chief Justice McLachlin went on to clarify what the Crown's underlying title amounts to:

The content of the Crown's underlying title is what is left when Aboriginal title is subtracted from it: s. 109 of the Constitution Act, 1867; Delgamuukw. As we have seen, Delgamuukw establishes that Aboriginal title gives "the right to exclusive use and occupation of the land ... for a variety of purposes", not confined to traditional or "distinctive" uses (para. 117). In other words, Aboriginal title is a beneficial interest in the land: Guerin, at p. 382. In simple terms, the title holders have the right to the benefits associated with the land - to use it, enjoy it and profit from its economic development. As such, the Crown does not retain a beneficial interest in Aboriginal title land. ${ }^{78}$

Aboriginal titleholders are therefore entitled to the entire benefit of the land, whereas the Crown's underlying title is limited to "two related elements - a fiduciary duty owed by the Crown to Aboriginal people when dealing with Aboriginal lands, and the right to encroach on Aboriginal title if the government can justify this in the broader public interest under s. 35 of the Constitution Act,

\footnotetext{
${ }^{76}$ See Tsilhqot'in Nation, B.C.S.C., above note 62 at paras. 267-86.

77 At common law, property rights are held by individuals and corporations, not by communities, so there is no common law in relation to communal rights that could apply directly in this context: see McNeil, “Exclusive Occupation”, above note 60 at 834-38, 860-71. Nor am I aware of any colonial, provincial, or federal legislation that would have applied to govern the internal dimension of Aboriginal title. Even today there is no such legislation, nor would it necessarily be constitutional, which is one reason why Indigenous law must apply to govern Aboriginal title internally: see McNeil, “Aboriginal Title and the Provinces”, above note 61.

${ }^{78}$ Tsilhqot'in Nation, S.C.C., above note 3 at para. 70.
} 
1982."79 Fiduciary obligations and encroachment do not relate directly to the issues of source, nature, and content of Aboriginal title - they involve constitutional issues that are outside the scope of our present discussion. ${ }^{80}$

\section{Conclusion}

In summary, the Tsilhqot'in Nation decision confirms that Aboriginal title comes from exclusive occupation of land at the time of Crown assertion of sovereignty, not from the Royal Proclamation of 1763. It is proprietary in nature and encompasses the entire beneficial interest in the land, subject to the inherent limit that the land cannot be used in ways that will substantially deprive future generations of its benefit. $^{81}$ The Crown's underlying title has no beneficial content whatsoever. The Aboriginal perspective, including Indigenous law, must be taken into account in assessing claims to Aboriginal title, but it is unclear from Chief Justice McLachlin's judgment whether this law's role is limited to being part of the evidence used to prove exclusive occupation. As I have argued, Indigenous law and authority should also govern the internal dimensions of Aboriginal title, while the common law

\footnotetext{
${ }^{79}$ Ibid. at para. 71. In my respectful opinion, the power to encroach on Aboriginal title flows not from the provincial Crown's underlying proprietary title derived from s.109 of the Constitution Act, 1867, but from its legislative authority under s.92 of that Act, especially s.92(13) which empowers provincial legislatures to enact laws in relation to "Property and Civil Rights in the Province”. See Tsilhqot'in Nation, S.C.C., above note 3 at paras. 102-03.

${ }^{80}$ See Kent McNeil, "Fiduciary Obligations and Aboriginal Peoples”, in Mark R. Gillen and Faye Woodman, eds., The Law of Trusts: A Contextual Approach, $3^{\text {rd }}$ ed. (Toronto: Emond Publishing, 2015), 839; Kent McNeil, “The Crown’s Fiduciary Obligations in the Era of Aboriginal Self-Government” (2009) 88 Can. Bar Rev. 1; McNeil, “Aboriginal Title and the Provinces", above note 61.

${ }^{81}$ McLachlin C.J. affirmed the inherent limit while modifying it so that it is less dependent on traditional uses: see note 19 above. In addition, and perhaps even more importantly, she said it also applies in the context of government infringement of Aboriginal title: "The beneficial interest in the land held by the Aboriginal group vests communally in the title-holding group. This means that incursions on Aboriginal title cannot be justified if they would substantially deprive future generations of the benefit of the land": Tsilhqot'in Nation, S.C.C., above note 3 at para. 86.
} 
governs the rights of the Indigenous titleholders as against the outside world. 